\title{
Effect of Planting Date and Calcium Spraying on Peanut Quality
}

\author{
Intsar H. H. Al-Hilfy' ${ }^{1}$ and Sinan A. A. Al-Salmani² \\ 1Dept. of Field Crops, Coll. of Agric., Univ. of Baghdad. Iraq \\ ${ }^{2}$ Dept. of Field Crops, Coll. of Agric., Univ. of Anbar. Iraq \\ Correspondence Author: Intsar H. H. Al-Hilfy, Dept. of Field Crops, Coll. of Agric., Univ. of Baghdad. \\ Email: Dr.intsar_hadi@yahoo.com
}

Received date: 23 February 2019, Accepted date: 22 May 2019, Online date: 30 May 2019

Copyright: (c) 2019 Intsar H. H. Al-Hilfy et al., This is an open-access article distributed under the terms of the Creative Commons Attribution License, which permits unrestricted use, distribution, and reproduction in any medium, provided the original author and source are credited.

\begin{abstract}
A Field experiment was carried out at one of Al-Mohmadi district agricultural fields, Heet district, Al-Anbar governorate, on the right bank of the Euphrates River, Iraq which is within longitude $42.82{ }^{\circ}$ and latitude $33.63{ }^{\circ}$ in sandy soil during 2012 and 2013 summer seasons to study the effect of planting dates and calcium spraying on seed quality of peanut (Local cv.). Factorial experiment in RCBD design with three replications and two factors was used, the first factor included six planting dates ( ${ }^{1}$ st April, $15^{\text {th }}$ April, $1^{\text {st }}$ May, $15^{\text {th }}$ May, $1^{\text {st }} J$ une and $15^{\text {th }}$ June) and the second factor included four levels of calcium $\left(0,200,400\right.$ and $\left.600 \mathrm{mg} \mathrm{Ca}^{-1}\right)$. Results showed that the highest oil percentage (48.33\% and $48.32 \%$ ) was produced from planting in $1^{\text {st }}$ and $15^{\text {th }}$ April in the first season and $49.42 \%$ was produced from planting in $15^{\text {th }}$ April in the second season, while the highest protein percentage was produced in $1^{\text {st }}$ June (about $25.25 \%$ and $27.45 \%$ ) for both seasons, respectively. The highest concentrations of calcium ( 400 and $600 \mathrm{mg} \mathrm{Ca} \mathrm{L}^{-1}$ ) were superior in protein percentage $23.27 \%, 23.42 \%$ and $23.42 \%, 23.16 \%$ for both seasons, respectively. The combination of $15^{\text {th }}$ May X $400 \mathrm{mg} \mathrm{Ca} \mathrm{L}^{-1}$ gave the highest Oleic acid $(55.66 \%)$ in the first season and $15^{\text {th }}$ May X $600 \mathrm{mg} \mathrm{Ca}^{-1}$ in the second season gave the highest Oleic acid $(54.00 \%)$.
\end{abstract}

Keywords: Peanut, calcium, planting date, seed quality

\section{INTRODUCTION}

Peanut (Arachis hypogaea L.) is an essential oil seed crop and food grain legume, grown widely in India (5.31M ha) with average productivity of $1.30 \mathrm{t}$ ha-1, while the USA was recorded highest productivity about $3.54 \mathrm{t}$ ha-1 as a source for oil and protein[1]. Seeds contain approximately $42-52 \%$ oil, $25-35 \%$ protein and $20 \%$ carbohydrate. Seeds also contain minerals (K, Ca, $\mathrm{Mg}, \mathrm{Fe}$ and $\mathrm{Zn}$ ) and vitamins (B, E, and $\mathrm{K}$ ), with good quality and high levels of unsaturated fatty acids (50\% oleic and $30 \%$ linoleic), so it is recommended in the nutrition to reduce low-density lipoprotein (LDL) [2]. Nutritional quality of the seed is influenced by several factors; environmental factors, genetic factors and their interaction [2, 3].

Agricultural processes, including planting dates, are factors influencing growth, production and quality of peanut due to variations in temperatures and photoperiod from time to time, affecting most of the vital processes and seed development[4, 5,6]. Al-Hilfy [4] observed significant increase in oil percent in delayed planting date from April to May, while the percentage of protein reduced from $29.08 \%$ to $28.74 \%$ as the planting date delayed from 10th May to 30th MaySharma et al. [7] concluded that oil percent did not differ significantly in delayed planting date from 20th April to 10th June.

Calcium is also a determining factor in the production of peanut through its effect on flowers fertilization, pods maturity and seed quality improvement $[8,9,10]$. Peanut plants need calcium when the pegs begin to appear and fruit formation so that the lack of available calcium leads to a high percentage of aborted seed [11,12]. Enough calcium content in the soil leads to increase survival of the symbiotic bacteria in peanut and that has a positive effect on nitrogen fixation, also leads to increase the growth, yield, oil and protein content [9]. The significant effect of calcium reflects the important role, which helps in increasing the availability of plant nutrients and nutrient uptake [8]. The climatic conditions are the main factors influencing the fatty acids composition oleic and linoleic acids, especially the variations in temperatures during seed filling stage [13]. Appropriate nutrient management, as well as sowing time, is necessary for attaining good yield and high peanut quality [14]. So, the objective of this study is to determine the effect of six sowing dates and four levels of calcium on seed quality of peanut. 


\section{MATERIALS AND METHODS}

A Field experiment was carried out during the summer seasons of 2012 and 2013 at one of Al-Mohmadi district agricultural fields, Heet district Al-Anbar governorate, on the right bank of the Euphrates River- Iraq, which is within longitude 42.82o and latitude $33.63 \mathrm{o}$ in sandy soil, to study the effect of sowing dates and calcium spraying in peanut crop (local cultivar). The soil of the experiment and crop service operations were prepared according to the recommendations [15].

A factorial experiment at randomized complete blocks design RCBD was used with three replicates. The first factor included six sowing dates (1st April, 15th April, 1st May, 15th May, 1st June and 15th June), while the second factor included three levels of calcium (200, 400 and $600 \mathrm{mg} \mathrm{Ca} \mathrm{L-1)}$ as well as the control treatment (sprayed with distilled water only) (Ca0). CaCl2 was used as a calcium source $(27.2 \% \mathrm{Ca})$. The experimental plots used in this experiment were 72 plots. Spraying was performed early in the morning at the beginning of the flowering stage using aback sprayer and Al-Zahi material was used as a diffuser to break up the surface tension. After maturity, ten plants of the middle rows in each plot were harvested. The seeds were dried and milled to determine the seed quality traits;

1. Oil seed content was determined using the Soxhlet method [16]

2. Protein seed content was determined by using MicroKjeldhal and calculated by multiplying the $\mathrm{N}$ percent, by converting factor $6.25[16]$

3. Oil yield $(\mathrm{t}$ ha- -1$)=$ oil $\% \times$ seed yield $(\mathrm{t}$ ha- 1$)$

4. Protein yield $(\mathrm{t}$ ha- 1$)=\%$ protein $\times$ seed yield $(\mathrm{t}$ ha- 1$)$

5. Saturated and unsaturated fatty acids: calculated by using MPA (Multi-Purpose Analyzer).

The recorded data were analyzed statistically by using the statistical software package Genstat version (12). The least significant differences (L.S.D) at the level of 0.05 probability was employed to compare the differences among the treatment means [17].

\section{RESULTS AND DISCUSSION}

\section{1-Oil seed content $(\%)$}

It is clear from Table 1 that the effect of sowing dates, calcium spraying levels, and their interaction in this trait was significant, for both seasons. Plants were sown in the first sowing date (1st April) during 2012 and the second sowing date (15th April) during 2013 gave highest oil percent (48.33\% and $49.42 \%$ ) for both seasons, respectively as compared to those sown on 15th June and 1st June which gave the lowest value due to high temperatures during seed filling stage and the environmental conditions differed during both seasons, where plants sown during 2013 season needed more heat units than plants sown during 2012 season, and this might be attributed to the effect of temperatures and light on growth stages at different sowing dates $[18,19]$. These results are in agreement with those obtained by other authors [18] who found the oil content of the later sowing date was significantly lower than early sowing. Regarding calcium spraying, plants sprayed with distilled water $(\mathrm{Ca} 0)$ gave highest oil percent $(46.49 \%$ and 46.20\%) while the plants sprayed with $600 \mathrm{mg} \mathrm{Ca} \mathrm{L-1} \mathrm{(44.37 \%} \mathrm{and} \mathrm{44.44 \% ).} \mathrm{These} \mathrm{results} \mathrm{are} \mathrm{in} \mathrm{harmony} \mathrm{with} \mathrm{those} \mathrm{obtained} \mathrm{by}$ Rahman [20].

Table 1: Effect of sowing dates and calcium spraying during 2012 (first row) and 2013 (second row) seasons on oil content (\%) of peanut.

\begin{tabular}{|c|c|c|c|c|c|}
\hline \multirow{2}{*}{ Sowing dates } & \multicolumn{4}{|c|}{ 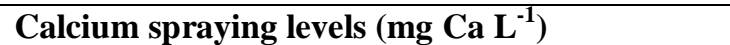 } & \multirow[b]{2}{*}{ Means } \\
\hline & Ca0 & Ca200 & Ca400 & Ca600 & \\
\hline \multirow{2}{*}{$1^{\text {st }}$ April } & 50.48 & 47.20 & 48.85 & 46.82 & 48.33 \\
\hline & 49.56 & 46.88 & 46.29 & 45.00 & 46.93 \\
\hline \multirow{2}{*}{$15^{\text {th }}$ April } & 49.58 & 48.07 & 48.24 & 47.42 & 48.32 \\
\hline & 50.00 & $09 . .48$ & 50.12 & 49.47 & 49.42 \\
\hline \multirow{2}{*}{$1^{\text {st }}$ may } & 48.31 & 47.24 & 46.68 & 46.91 & 47.28 \\
\hline & 48.10 & 47.84 & 45.95 & 46.19 & 47.02 \\
\hline \multirow{2}{*}{$15^{\text {th }}$ may } & 46.64 & 44.34 & 43.65 & 44.68 & 44.82 \\
\hline & 44.18 & 43.18 & 42.93 & 43.56 & 43.46 \\
\hline \multirow{2}{*}{$1^{\text {st June }}$} & 42.27 & 41.55 & 40.58 & 40.37 & 41.19 \\
\hline & 43.14 & 41.36 & 41.34 & 40.89 & 40.68 \\
\hline \multirow{2}{*}{$15^{\text {th }}$ June } & 41.68 & 41.70 & 41.03 & 40.01 & 41.10 \\
\hline & 27,42 & 42.00 & 41.87 & 41.53 & 41.91 \\
\hline \multirow{2}{*}{ Means } & 46.49 & 45.01 & 44.83 & 44.37 & \\
\hline & 46.20 & 444.89 & 44.75 & 44.44 & \\
\hline \multirow{3}{*}{ L.S.D. $5 \%$} & Sowing dates & Calcium & \multicolumn{2}{|c|}{ Sowing dates $\times$ calcium } & \\
\hline & 0.83 & 0.68 & \multicolumn{2}{|l|}{1.66} & \\
\hline & 0.71 & 0.58 & \multicolumn{2}{|l|}{1.42} & \\
\hline
\end{tabular}

Regarding the interaction between the two studied factors, combination control treatment sown at 1st April during 2012 was superior in oil percent about 50.48\% while $400 \mathrm{mg} \mathrm{Ca} \mathrm{L-1} \mathrm{sown} \mathrm{at} \mathrm{15th} \mathrm{April} \mathrm{during} 2013$ gave highest oil percent (50.12\%). 
Citation: Intsar H. H. Al-Hilfy et al., 2019. Effect of Planting Date and Calcium Spraying on Peanut Quality. Advances in Environmental Biology 13(5): 7-13. DOI: $10.22587 /$ aeb.2019.13.5.2

\section{2-protein content $(\%)$}

Results in table 2 showed that there were significant differences in protein percentage regarding sowing dates and the interaction for both seasons, while calcium spraying levels was significant during the 2012 season only.

Plants sown in the fifth sowing date (1st June) gave highest protein percent (25.28 and $27.48 \%)$ for both seasons, respectively, while the lowest value was in 1st May (20.72\%) during 2012 and in the second sowing date (15th April) during 2013 (19.44\%), and this might be attributed to the effect of high temperatures during seed filling causes reduction in oil content and an increase in protein content because of the negative relation between them [21].

Regarding calcium spraying, plants sprayed with $600 \mathrm{mg} \mathrm{Ca} \mathrm{L-1} \mathrm{gave} \mathrm{highest} \mathrm{protein} \mathrm{percent} \mathrm{(23.42 \% )} \mathrm{during} 2012$ season as compared to the control treatment, which gave the lowest value $(21.47 \%)$. These results are in agreement with those obtained by other authors $[8,9]$.

Regarding the interaction plants sown on 1st June and sprayed with $600 \mathrm{mg} \mathrm{Ca} \mathrm{L-1}$ gave highest protein percent (25.99\% and $28.64 \%)$ as compared to plants sown in 1st April with the control treatment which gave the lowest value (18.93\% and 19.34\%) for both seasons.

Table 2: Effect of sowing dates and calcium spraying during 2012 (first row) and 2013 (second row) seasons on protein content (\%) of peanut.

\begin{tabular}{|c|c|c|c|c|c|}
\hline \multirow{2}{*}{ Sowing dates } & \multicolumn{4}{|c|}{ Calcium spraying levels $\left(\mathrm{mg} \mathrm{CaL}^{-1}\right)$} & \multirow{2}{*}{ Means } \\
\hline & Ca0 & Ca200 & Ca400 & Ca600 & \\
\hline \multirow{2}{*}{$1^{\text {st }}$ April } & 18.93 & 21.18 & 22.77 & 23.48 & 21.59 \\
\hline & 19.34 & 20.15 & 22.40 & 24.48 & 21.59 \\
\hline \multirow{2}{*}{$15^{\text {th }}$ April } & 20.51 & 21.53 & 21.98 & 22.14 & 21.54 \\
\hline & 18.55 & 20.06 & 19.05 & 20.11 & 19.44 \\
\hline \multirow{2}{*}{$1^{\mathrm{st}}$ may } & 20.56 & 21.10 & 23.11 & 22.98 & 21.93 \\
\hline & 20.91 & 20.12 & 22.37 & 21.22 & 21.15 \\
\hline \multirow{2}{*}{$15^{\text {th }}$ may } & 20.99 & 19.06 & 21.58 & 21.28 & 20.72 \\
\hline & 24.42 & 25.11 & 22.26 & 22.17 & 23.49 \\
\hline \multirow{2}{*}{$1^{\text {st }}$ June } & 24.44 & 24.85 & 25.86 & 25.99 & 25.28 \\
\hline & 25.27 & 27.80 & 28.09 & 28.64 & 27.45 \\
\hline \multirow{2}{*}{$15^{\text {th }}$ June } & 23.42 & 23.63 & 24.32 & 24.68 & 24.01 \\
\hline & 23.62 & 23.75 & 24.78 & 24.51 & 24.16 \\
\hline \multirow{2}{*}{ Means } & 21.47 & 21.89 & 23.27 & 23.42 & \\
\hline & 22.02 & 22.83 & 23.16 & 23.52 & \\
\hline \multirow{3}{*}{ L.S.D. $5 \%$} & Sowing dates & Calcium & \multicolumn{2}{|c|}{ Sowing dates $\times$ Calcium } & \\
\hline & 0.41 & 0.33 & \multicolumn{2}{|l|}{0.81} & \\
\hline & 0.92 & $N . S$ & \multicolumn{2}{|l|}{1.84} & \\
\hline
\end{tabular}

\section{3-oil yield (t ha -1)}

Results in Table 3 show that there were significant differences in oil yield regarding sowing dates, calcium spraying levels and the interaction between them for both seasons.

Plants sown on 15th April during 2012 recorded highest yield of oil about $1.925 \mathrm{t}$ ha-1 and in increasing $109.24 \%$ compared to the sowing date 15th June which gave the lowest value, also during 2013 the sowing date 15th April gave the highest yield of oil $2.176 \mathrm{t}$ ha- 1 and in increasing $111.63 \%$ compared to the sowing date 15 th June which gave the lowest mean. This increase might be attributed to the high yield of seeds and high oil content in early sowing as compared to late sowing dates.

Regarding calcium, spraying results show that plants sprayed with $400 \mathrm{mg}$ Ca L-1 gave highest oil yield 1.644 and 1.723 t ha-1 for both seasons due to high yield of seed and high oil content, while the lowest values were noticed with control treatment. Regarding the interaction, the combination plants sown on 1st April during 2012 and 15th April during 2013 and sprayed with 400 mg Ca L-1 gave highest oil yield 2.099 and 2.363 t ha-1 for both seasons, respectively.

\section{4- Protein yield (t ha -1)}

Data in Table 3 showed that the effect of sowing dates and calcium spraying levels in this trait were significant for both seasons. Peanut plants sown on 1st May recorded the highest yield of protein about 0.876 and $0.888 \mathrm{t}$ ha- 1 compared to the sowing date 15 th June which gave the lowest values $(0.539$ and $0.594 \mathrm{t}$ ha- 1$)$ for both seasons, respectively. This might be due to the variation in weather condition on seed yield of peanut, and that reflects on protein yield [22].

Regarding calcium spraying, plants sprayed with $600 \mathrm{mg} \mathrm{Ca} \mathrm{L-1} \mathrm{gave} \mathrm{the} \mathrm{highest} \mathrm{yield} \mathrm{of} \mathrm{protein}(0.838$ and $0.870 \mathrm{t}$ ha -1$)$ compared to control which gave lowest values $(0.561$ and $0.599 \mathrm{t}$ ha -1$)$ for both seasons, respectively. This increase might be due to the role of calcium in increasing seed yield and protein content (8). These results are in agreement with those obtained by Gashti et al.,[9] who found an increase in the content of protein as a result of calcium application. 
Table 3: Effect of sowing dates and calcium spraying during 2012 (first row) and 2013 (second row) seasons on oil yield (t ha-1) of peanut.

\begin{tabular}{|c|c|c|c|c|c|}
\hline \multirow{2}{*}{ Sowing dates } & \multicolumn{4}{|c|}{ Calcium spraying levels $\left(\mathrm{mg} \mathrm{CaL}^{-1}\right)$} & \multirow{2}{*}{ Means } \\
\hline & $\mathrm{CaO}$ & Ca200 & Ca400 & Ca600 & \\
\hline \multirow{2}{*}{$1^{s t}$ April } & 1.525 & 1.898 & 2.099 & 1.975 & 1.874 \\
\hline & 1.370 & 1.780 & 1.911 & 1.784 & 1.711 \\
\hline \multirow{2}{*}{$15^{\text {th }}$ April } & 1.596 & 2.009 & 2.071 & 2.026 & 1.925 \\
\hline & 1.877 & 2.201 & 2.363 & 2.266 & 2.176 \\
\hline \multirow{2}{*}{$1^{s t}$ may } & 1.491 & 1.987 & 2.012 & 2.017 & 1.876 \\
\hline & 1.698 & 2.088 & 2.017 & 2.077 & 1.970 \\
\hline \multirow{2}{*}{$15^{\text {th }}$ may } & 1.217 & 1.625 & 1.521 & 1.605 & 1.492 \\
\hline & 1.010 & 1.475 & 1.540 & 1.608 & 1.408 \\
\hline \multirow{2}{*}{$1^{\text {st }}$ June } & 0.892 & 1.158 & 1.181 & 1.155 & 1.096 \\
\hline & 0.992 & 1.284 & 1.410 & 1.307 & 1.248 \\
\hline \multirow{2}{*}{$15^{\text {th }}$ June } & 0.732 & 0.995 & 0.983 & 0.971 & 0.920 \\
\hline & 0.875 & 1.052 & 1.100 & 1.086 & 1.028 \\
\hline \multirow{2}{*}{ Means } & 1.242 & 1.612 & 1.644 & 1.624 & \\
\hline & 1.303 & 1.646 & 1.723 & 1.688 & \\
\hline \multirow{3}{*}{ L.S.D. $5 \%$} & Sowing dates & Calcium & \multicolumn{2}{|c|}{ Sowing dates $\times$ Calcium } & \\
\hline & 0.13 & 0.10 & \multicolumn{2}{|l|}{0.26} & \\
\hline & 0.11 & 0.09 & \multicolumn{2}{|l|}{0.22} & \\
\hline
\end{tabular}

Table 4: Effect of sowing dates and calcium spraying during 2012 (first row) and 2013 (second row) seasons on protein yield (t ha-1) of peanut.

\begin{tabular}{|c|c|c|c|c|c|}
\hline \multirow{2}{*}{ Sowing dates } & \multicolumn{4}{|c|}{ Calcium spraying levels $\left(\mathrm{mg} \mathrm{CaL}^{-1}\right)$} & \multirow{2}{*}{ Means } \\
\hline & $\mathrm{CaO}$ & Ca200 & Ca400 & Ca600 & \\
\hline \multirow{2}{*}{$1^{s t}$ April } & 0.572 & 0.851 & 0.978 & 0.990 & 0.847 \\
\hline & 0.534 & 0.765 & 0.925 & 0.970 & 0.798 \\
\hline \multirow{2}{*}{$15^{\text {th }}$ April } & 0.660 & 0.900 & 0.943 & 0.946 & 0.862 \\
\hline & 0.696 & 0.918 & 0.898 & 0.921 & 0.858 \\
\hline \multirow{2}{*}{$1^{s t}$ may } & 0.634 & 0.887 & 0.996 & 0.988 & 0.876 \\
\hline & 0.738 & 0.878 & 0.982 & 0.954 & 0.888 \\
\hline \multirow{2}{*}{$15^{\text {th }} \mathrm{may}$} & 0.572 & 0.698 & 0.752 & 0.764 & 0.696 \\
\hline & 0.559 & 0.858 & 0.798 & 0.818 & 0.758 \\
\hline \multirow{2}{*}{$1^{\text {st }}$ June } & 0.516 & 0.692 & 0.753 & 0.743 & 0.676 \\
\hline & 0.581 & 0.863 & 0.958 & 0.916 & 0.829 \\
\hline \multirow{2}{*}{$15^{\text {th }}$ June } & 0.411 & 0.564 & 0.583 & 0.600 & 0.539 \\
\hline & 0.489 & 0.595 & 0.651 & 0.641 & 0.594 \\
\hline \multirow{2}{*}{ Means } & 0.561 & 0.765 & 0.834 & 0.838 & \\
\hline & 0.599 & 0.812 & 0.868 & 0.870 & \\
\hline \multirow{3}{*}{ L.S.D. $5 \%$} & Sowing dates & Calcium & \multicolumn{2}{|c|}{ Sowing dates $\times$ Calcium } & \\
\hline & 0.110 & 0.090 & \multicolumn{2}{|l|}{$N . S$} & \\
\hline & 0.194 & 0.158 & \multicolumn{2}{|l|}{$N . S$} & \\
\hline
\end{tabular}

5--Saturated and unsaturated fatty acids $(\%)$

The percentage of saturated and unsaturated fatty acids were significantly influenced by sowing dates, calcium spraying levels, and their interactions (Tables 5,6,7, and 8). There was a significant increase in the means of oleic acid at sowing date on 15th May $(52.55 \%$ and $52.90 \%)$, respectively.

Seeds obtained from 15th May sowing date contain low means of linoleic (32.13\% and 31.98\%), palmitic (11.91\% and 11.76\%) and stearic acids $(2.16 \%$ and $2.09 \%)$ for both seasons, respectively. This reduction could be due to the variation in temperatures during seed filling stage and shorten growth duration that was not enough to precipitate these acids completely because of linoleic acid formation was occurred two weeks later fertilization while oleic acid formation was occurred immediately after pollination $[6,23]$. In addition to being the activity of the desaturase enzyme that converts oleic to linoleic acid decreased as the temperature increases [23].

As for calcium spraying, plants sprayed with $600 \mathrm{mg} \mathrm{Ca} \mathrm{L-1} \mathrm{during} 2012$ gave highest mean of oleic acid (51.56\%), while 200 mg Ca L-1 gave the lowest mean (50.33\%), whereas spraying, plants with $200 \mathrm{mg}$ Ca L-1 during 2013 season gave highest mean of oleic acid (51.44\%) with no significant differences from $400 \mathrm{mg} \mathrm{Ca} \mathrm{L-1} \mathrm{and} 600 \mathrm{mg} \mathrm{Ca} \mathrm{L-1} \mathrm{(} 51.33 \%$ and 51.07\%), respectively in comparison with control which gave the lowest mean of oleic $50.34 \%$.

On the other hand, plants sprayed with $200 \mathrm{mg}$ Ca L-1 during 2012 and the control treatment during 2013 season gave highest means of linoleic acid (34.02\% and 34.24\%), respectively in comparison with $400 \mathrm{mg}$ Ca L-1 which gave lowest mean of this acid $33.11 \%$ for both season, respectively and this beyond to negative relationship between oleic and linoleic acids. 
Citation: Intsar H. H. Al-Hilfy et al., 2019. Effect of Planting Date and Calcium Spraying on Peanut Quality. Advances in Environmental Biology 13(5): 7-13. DOI: $10.22587 / \mathrm{aeb} .2019 .13 .5 .2$

Regarding palmitic acid, the highest means were from plants sprayed with $400 \mathrm{mg}$ Ca L-1 (12.51\% and $12.45 \%)$ compared to lowest means for the control treatment $(12.29 \%$ and $12.02 \%)$ for both seasons, respectively.

Also, the highest means of stearic acid (2.40\% and 2.30\%) were recorded with control treatment and with $200 \mathrm{mg}$ Ca L-1 during 2012 and 2013 seasons, respectively compared to lowest means (2.09\% and 2.13\%) from plants sprayed with $600 \mathrm{mg}$ Ca L-1.

As shown in Tables 5, 6, 7 and 8 the interaction between the two factors was significant in all studied fatty acids, the results showed that the plants sprayed with $400 \mathrm{mg} \mathrm{Ca} \mathrm{L-1} \mathrm{and} \mathrm{sown} \mathrm{in} \mathrm{15th} \mathrm{May} \mathrm{during} 2012$ season gave highest mean of oleic acid $53.66 \%$ conversely plants sprayed with $600 \mathrm{mg} \mathrm{Ca} \mathrm{L-1} \mathrm{sown} \mathrm{in} \mathrm{15th} \mathrm{May} \mathrm{during} 2013$ season gave the highest mean of this acid $(54 \%)$.

Results in Table 6 show that the interaction between plants sprayed with $200 \mathrm{mg}$ Ca L-1 and sown in 15 th April during 2012 season gave the highest mean of linoleic acid 35.99\% conversely the plants in control sown in 1st April during 2013 season gave a highest mean of linoleic acids $(36.50 \%)$.

The interaction regarding palmatic acid (Table 7), plants sprayed with $200 \mathrm{mg} \mathrm{Ca} \mathrm{L-1} \mathrm{and} \mathrm{sown} \mathrm{in} 1$ st April during 2012 season gave the highest mean of palmitic acid $13.26 \%$ conversely the plants sprayed with $600 \mathrm{mg} \mathrm{Ca} \mathrm{L-1} \mathrm{and} \mathrm{sown} \mathrm{in} 1$ st April during 2013 season gave highest mean $(13.43 \%)$.

In Table 8 the interaction regarding stearic acid, plants sprayed with $400 \mathrm{mg} \mathrm{Ca} \mathrm{L-1}$ and sown in 15 th April during 2012 season gave the highest mean of stearic acid $2.78 \%$, conversely the plants sprayed with $200 \mathrm{mg} \mathrm{Ca} \mathrm{L-1} \mathrm{and} \mathrm{sown} \mathrm{in} 15$ th April during 2013 season gave the highest mean of this acid (3.00\%).

Table 5: Effect of sowing dates and calcium spraying during 2012 (first row) and 2013 (second row) seasons on oleic acid (\%) of peanut.

\begin{tabular}{|c|c|c|c|c|c|}
\hline \multirow{2}{*}{ Sowing dates } & \multicolumn{4}{|c|}{ Calcium spraying levels $\left(\mathrm{mg} \mathrm{Ca} \mathrm{L}^{-1}\right)$} & \multirow{2}{*}{ Means } \\
\hline & Ca0 & Ca200 & Ca400 & Ca600 & \\
\hline \multirow{2}{*}{$1^{\text {st }}$ April } & 49.93 & 48.27 & 51.70 & 50.40 & 50.07 \\
\hline & 48.23 & 50.57 & 50.93 & 49.27 & 49.75 \\
\hline \multirow{2}{*}{$15^{\text {th }}$ April } & 49.70 & 49.00 & 51.01 & 52.04 & 50.43 \\
\hline & 50.07 & 51.27 & 48.73 & 50.19 & 50.07 \\
\hline \multirow{2}{*}{$1^{\mathrm{st}}$ may } & 51.13 & 52.00 & 51.27 & 52.67 & 51.76 \\
\hline & 51.08 & 52.60 & 52.30 & 52.00 & 52.00 \\
\hline \multirow{2}{*}{$15^{\text {th }}$ may } & 53.00 & 51.33 & 53.66 & 52.20 & 52.55 \\
\hline & 52.37 & 52.10 & 53.12 & 54.00 & 52.90 \\
\hline \multirow{2}{*}{$1^{\text {st }}$ June } & 49.63 & 51.00 & 50.04 & 51.13 & 50.45 \\
\hline & 51.23 & 52.00 & 51.83 & 50.23 & 51.32 \\
\hline \multirow{2}{*}{$15^{\text {th }}$ June } & 49.90 & 50.40 & 49.50 & 50.93 & 50.18 \\
\hline & 49.11 & 50.13 & 51.07 & 50.77 & 50.27 \\
\hline \multirow{2}{*}{ Means } & 50.54 & 50.33 & 51.20 & 51.56 & \\
\hline & 50.34 & 51.44 & 51.33 & 51.07 & \\
\hline \multirow{3}{*}{ L.S.D. $5 \%$} & Sowing dates & Calcium & \multicolumn{2}{|c|}{ Sowing dates $\times$ calcium } & \\
\hline & 0.83 & 0.68 & \multicolumn{2}{|l|}{1.66} & \\
\hline & 1.15 & 0.94 & \multicolumn{2}{|l|}{2.30} & \\
\hline
\end{tabular}

Table 6: Effect of sowing dates and calcium spraying during 2012 (first row) and 2013 (second row) seasons on linoleic acid \% of peanut.

\begin{tabular}{|c|c|c|c|c|c|}
\hline \multirow{2}{*}{ Sowing dates } & \multicolumn{4}{|c|}{ Calcium spraying levels $\left(\mathrm{mg} \mathrm{Ca} \mathrm{L}^{-1}\right)$} & \multirow{2}{*}{ Means } \\
\hline & $\mathrm{CaO}$ & Ca200 & Ca400 & Ca600 & \\
\hline \multirow{2}{*}{$1^{\text {st }}$ April } & 34.11 & 35.14 & 32.93 & 34.36 & 34.13 \\
\hline & 36.50 & 34.35 & 34.50 & 34.33 & 34.92 \\
\hline \multirow{2}{*}{$15^{\text {th }}$ April } & 34.46 & 35.99 & 33.06 & 34.36 & 34.46 \\
\hline & 34.37 & 34.00 & 35.07 & 34.70 & 34.53 \\
\hline \multirow{2}{*}{$1^{\text {st }}$ may } & 33.87 & 33.00 & 32.70 & 32.12 & 32.92 \\
\hline & 32.27 & 31.97 & 32.13 & 32.44 & 32.20 \\
\hline \multirow{2}{*}{$15^{\text {th }}$ may } & 32.06 & 32.61 & 31.11 & 32.77 & 32.13 \\
\hline & 32.70 & 31.86 & 31.43 & 31.93 & 31.98 \\
\hline \multirow{2}{*}{$1^{\text {st }}$ June } & 34.49 & 34.00 & 33.99 & 33.60 & 34.02 \\
\hline & 33.93 & 33.27 & 32.46 & 34.88 & 33.63 \\
\hline \multirow{2}{*}{$15^{\text {th }}$ June } & 34.03 & 33.41 & 34.87 & 33.13 & 33.86 \\
\hline & 35.73 & 33.47 & 33.10 & 33.03 & 33.83 \\
\hline \multirow{2}{*}{ Means } & 33.83 & 34.02 & 33.11 & 33.39 & \\
\hline & 34.24 & 33.15 & 33.11 & 33.38 & \\
\hline \multirow{3}{*}{ L.S.D. $5 \%$} & Sowing dates & Calcium & \multicolumn{2}{|c|}{ Sowing dates $\times$ calcium } & \\
\hline & 0.26 & 0.22 & \multicolumn{2}{|l|}{0.53} & \\
\hline & 0.19 & 0.16 & \multicolumn{2}{|l|}{0.39} & \\
\hline
\end{tabular}


Table 7: Effect of sowing dates and calcium spraying during 2012 (first row) and 2013 (second row) seasons on palmitic acid (\%) of peanut.

\begin{tabular}{|c|c|c|c|c|c|}
\hline \multirow{2}{*}{ Sowing dates } & \multicolumn{4}{|c|}{ Calcium spraying levels (mg Ca $\mathrm{L}^{-1}$ ) } & \multirow{2}{*}{ Means } \\
\hline & Ca0 & Ca200 & Ca400 & Ca600 & \\
\hline \multirow{2}{*}{$1^{\text {st }}$ April } & 13.03 & 13.26 & 13.20 & 13.00 & 13.12 \\
\hline & 12.43 & 13.00 & 12.03 & 13.43 & 12.72 \\
\hline \multirow{2}{*}{$15^{\text {th }}$ April } & 12.53 & 12.33 & 12.33 & 12.63 & 12.45 \\
\hline & 12.20 & 11.26 & 13.33 & 12.20 & 12.24 \\
\hline \multirow{2}{*}{$1^{\text {st }}$ may } & 11.78 & 12.04 & 12.21 & 12.04 & 12.01 \\
\hline & 11.61 & 12.20 & 12.09 & 12.33 & 12.05 \\
\hline \multirow{2}{*}{$15^{\text {th }}$ may } & 11.90 & 11.89 & 12.05 & 11.83 & 11.91 \\
\hline & 11.79 & 12.00 & 12.10 & 11.16 & 11.76 \\
\hline \multirow{2}{*}{$1^{\text {st }}$ June } & 12.40 & 12.20 & 12.90 & 12.26 & 12.44 \\
\hline & 12.13 & 12.16 & 12.56 & 12.07 & 12.23 \\
\hline \multirow{2}{*}{$15^{\text {th }}$ June } & 12.11 & 12.26 & 12.40 & 12.00 & 12.19 \\
\hline & 11.98 & 12.53 & 12.59 & 12.89 & 12.49 \\
\hline \multirow{2}{*}{ Means } & 12.29 & 12.33 & 12.51 & 12.29 & \\
\hline & 12.02 & 12.19 & 12.45 & 12.34 & \\
\hline \multirow{3}{*}{ L.S.D. $5 \%$} & Sowing dates & Calcium & \multicolumn{2}{|c|}{ Sowing dates $\times$ calcium } & \\
\hline & 0.17 & 0.14 & \multicolumn{2}{|l|}{0.35} & \\
\hline & 0.11 & 0.09 & \multicolumn{2}{|l|}{0.21} & \\
\hline
\end{tabular}

Table 8: Effect of sowing dates and calcium spraying during 2012 (first row) and 2013 (second row) seasons on stearic acid (\%) of peanut.

\begin{tabular}{|c|c|c|c|c|c|}
\hline \multirow{2}{*}{ Sowing dates } & \multicolumn{4}{|c|}{ Calcium spraying levels (mg Ca $\mathrm{L}^{-1}$ ) } & \multirow{2}{*}{ Means } \\
\hline & Ca0 & Ca200 & Ca400 & Ca600 & \\
\hline \multirow{2}{*}{$1^{\text {st }}$ April } & 2.64 & 2.55 & 2.66 & 2.01 & 2.46 \\
\hline & 2.30 & 2.00 & 2.73 & 2.42 & 2.36 \\
\hline \multirow{2}{*}{$15^{\text {th }}$ April } & 2.26 & 2.06 & 2.78 & 2.04 & 2.28 \\
\hline & 2.33 & 3.00 & 1.98 & 2.03 & 2.33 \\
\hline \multirow{2}{*}{$1^{\mathrm{st}}$ may } & 2.56 & 2.30 & 2.40 & 2.33 & 2.39 \\
\hline & 2.43 & 2.30 & 2.36 & 2.40 & 2.36 \\
\hline \multirow{2}{*}{$15^{\text {th }}$ may } & 2.45 & 2.10 & 2.12 & 2.00 & 2.16 \\
\hline & 2.19 & 2.03 & 2.11 & 2.06 & 2.09 \\
\hline \multirow{2}{*}{$1^{\text {st }}$ June } & 2.21 & 2.29 & 2.20 & 2.22 & 2.23 \\
\hline & 2.13 & 2.23 & 2.20 & 2.00 & 2.13 \\
\hline \multirow{2}{*}{$15^{\text {th }}$ June } & 2.31 & 2.18 & 2.21 & 2.01 & 2.17 \\
\hline & 2.33 & 2.26 & 2.25 & 1.90 & 2.18 \\
\hline \multirow{2}{*}{ Means } & 2.40 & 2.24 & 2.39 & 2.09 & \\
\hline & 2.28 & 2.30 & 2.27 & 2.13 & \\
\hline \multirow{3}{*}{ L.S.D. $5 \%$} & Sowing dates & Calcium & \multicolumn{2}{|c|}{ Sowing dates $\times$ calcium } & \\
\hline & 0.28 & 0.23 & \multicolumn{2}{|l|}{0.57} & \\
\hline & 0.19 & 0.16 & \multicolumn{2}{|l|}{0.39} & \\
\hline
\end{tabular}

\section{REFERENCES}

1. Thamaraikannan, M., G. Palaniappan and S. Dhamalingam. 2009. Groundnut the King of Oilseeds. Market Survey, India.

2. Isleib, T. G., M. B. L. Tillman, H. E. Pattee, T. H. Sanders, K. W. Hendrix and L. O. Dean. 2008. Genotype-by-environment interaction for flavor attributes of breeding lines in the uniform peanut performance test. Peanut Sci., 35: 55-60.

3. Norman, K., L. Wieck, P. Harden and G. Baker. 2005. Peanut production guide. National Library of Australia Cataloguing. pp. 36.

4. Al-Hilfy, I. H. H. 2001. Effect of dates for planting and harvesting on yield and quality of peanut (Arachis hypogaea L.). Ph.D. Dissertation, Dept. of Field Crops, Coll. of Agric., Univ. of Baghdad. pp.110.

5. Calishkan, S. M., E. Calishkan, M. Arsl and H. Ariogu. 2008. Effects of sowing date and growth duration on growth and yield of groundnut in a Mediterranean- type environment in Turkey. Field Crops Res., 105(1-2): 131-14

6. Meena, R. S., R. S. Yadav and V. S. Meena. 2014. Response of groundnut (Arachis hypogaea L.) verities to sowing dates and NP fertilizers under Western dry zone of India. Bangladesh J. Bot., 43(2): 169-137.

7. Sharma, P., V. Sardana and S. S. kandhola. 2013. Effect of sowing dates and harvesting dates on germination and seedling vigor of groundnut (Arachis hypogaea L.) cultivars. J. Res. Seed Sci. 6(1): 1-15. 
8. Helmy, A. M. and M. F. Ramdan. 2014. Yield quality parameters and chemical composition of peanut as affected by potassium and gypsum application under foliar spraying with boron. Communications in Soil Science and Plant Analysis, 45(18): 2397-2412.

9. Gashti, A. H., M. N. S. Vishekaei and M. H. Hosseinzadeh. 2012. Effect of potassium and calcium application on yield components and qualitative characteristics of peanut (Arachis hypogaea L.) in Guilan province, Iran. World Appl. Sci. J., 16(4): 540-546.

10. Al-Dulami, H. M. M. 2000. Agricultural applications on the peanut (Arachis hypogaea L.). Ph.D. Dissertation, Dept. of Field Crops, Coll. of Agric., Univ. of Baghdad. pp. 116.

11. Ntare, B. R., A. T. Diallo, A .T. Ndjeun and F. Waliyar, 2008. Groundnut Seed Production Manual ,Program International Crop Institute for the Semi-Arid Tropics, Patancheru, Andra Prades, 502324,India.

12. Kabir, R., S. Yeasmin, A. K. Islam and M. A. R. Sarkan. 2013. Effect of phosphorus, calcium and boron on the growth and yield of groundnut (Arachis hypogaea L.) Inter. J. Biol. Sci. and Biol. Technol., 5 (3): 51-59.

13. Andersen, P. C. and D. W. Gorbet. 2002. Influence of year and planting date on fatty acid chemistry of high oleic acid and normal peanut genotypes. J. Agric. Food Chem. 50(5): 1298-1305.

14. Halder, D. and R. K. Panda. 2014. Determination of appropriate sowing date and phosphorus fertilization strategy for peanut in Eastern India. Afric. J. of Agric. Res. 9(32): 2475-2487.

15. Ali, H. S. and S. F. Hassan. 2011. Peanut cultivation and production in Iraq. Directorate of Agric., Res., Ministry of Agric., pp. 23.

16. A.O.A.C 1990.Official Methods of Analysis 15th edition.Association of Official Analytical Chemists International Arlington, VA, D.C., USA.

17. Steel, R.G.D., J.H. Torrie and D.A. Dickey, 1997. Principles and procedures of statistics: a biometric approach, 3rd Ed. McGraw Hill Book Co. Inc., New York. USA.

18. Sardana, V. and S. S. Kandhola. 2007. Productivity of semi-spreading and bunch type verities of groundnut as influenced by sowing dates. J. SAT Agric. Res., 5(1): 1-4.

19. Padmalatha,V., D. R. Reddy and T. Y.Reddy. 2006. The relationship between weather parameters during developmental phase and fruit attributes and yield of peanut. Peanut Sci., 33(2):118-124.

20. Rahman, M. A. 2006. Effect of calcium and Bradyrhizobium inoculation of the growth, yield and quality of groundnut (Arachis hypogaea L.) Bangladesh. J. Sci. Ind. Res. 41: 181-188.

21. Brown, D. F., C. M. Cater, K. F. Mattil and J. G. Darroch. 1975. Effect of variety, growing Location and their interaction on the fatty acid composition of peanuts. J. of Food Sci. 40: 1056-1064.

22. Guled, P. M., A. M. Shekh, V. Pandey and H. R. Patel. 2013. Effect of weather conditions on kharif groundnut (Arachis hypogaea L.) at Anand in middle Gujarat agro-climatic zone. Asian J. Environ. Sci. 8(2): 72-76.

23. Dwivedi S.L. , S.N. Nigam, R.C. Nageswara Rao, U. Singh and K .V.S. Rao . 2013. Effect of drought on oil, fatty acids and protein contents of groundnut (Arachis hypogaea L.) seeds Field Crops Research 48:125-133. 